\title{
The Effect of Guided Inquiry Learning Model on Creativity and Linguistic Ability Viewed from Social Interaction Ability among Kindergarten Children of Group B
}

\author{
I Made Elia Cahaya ${ }^{1}$ \\ Ketut Suarni ${ }^{2}$ (iD \\ Nyoman Dantes ${ }^{3}$ \\ I Gede Margunayasa ${ }^{4}$
}

${ }^{1,2, s, 4}$ Universitas Pendidikan Ganesha, Indonesia.

Email:madeeliacahava@gmail.com Tel:081353275678

EEmail:niketut.suarni@undiksha.ac.id Tel:087863003014

${ }^{3}$ Email: dantes@undiksha.ac.id Tel:0819161027ss

"Email: igede.margunayasa@undiksha.ac.id Tel:081805536270

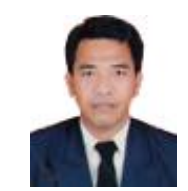

\begin{abstract}
This study analyzed the effect of guided inquiry learning model on creativity viewed from social interaction skill of the kindergarten children of group B in North Kuta district, Badung regency. This study used the $2 \times 2$ factorial design. The population was all kindergarten B's in the North Kuta district with the total of 1.951 children from 49 schools, divided into 7 clusters. The sample was drawn by multistage random sampling technique creating 8 learning groups with 4 experimental groups and 4 control groups each of which consisted of 76 children. The study used a child's social interaction ability observation sheet and a child's creativity observation sheet as the instruments. The data were analyzed using two-way ANOVA. The data analysis revealed that (1) there is a significant difference in child's creativity between children who learned with guided inquiry learning model and those who learned with conventional teaching model $(\mathrm{F}=18.874$; $\mathrm{p}<0.05)$ and $(2)$ there is a significant interaction effect between learning model and social interaction ability on creativity $(\mathrm{F}=15.975 ; \mathrm{p}<0.05)$. The children who had a high social interaction would be more efficient if they were taught by using guided inquiry learning model in achieving the students' creativity, meanwhile the students who had a low social interaction would be more efficient if they were taught by using conventional learning model.
\end{abstract}

Keywords: Guided inquiry learning model, Social interaction, Creativity.

Citation | I Made Elia Cahaya; Ketut Suarni; Nyoman Dantes; I Gede Margunayasa (2020). The Effect of Guided Inquiry Learning Model on Creativity and Linguistic Ability Viewed from Social Interaction Ability among Kindergarten Children of Group B. Journal of Education and e-Learning Research, 7(4): 421-429. History:

Received: 9 September 2020 Revised: 30 September 2020 Accepted: 23 October 2020

Published: 3 November 2020

Licensed: This work is licensed under a Creative Commons

Attribution 3.0 License $(\mathrm{cc})$ EY

Publisher: Asian Online Journal Publishing Group
Acknowledgement: All authors contributed to the conception and design of the study.

Funding: This study received no specific financial support.

Competing Interests: The authors declare that they have no conflict of interests.

Transparency: The authors confirm that the manuscript is an honest, accurate, and transparent account of the study was reported; that no vital features of the study have been omitted; and that any discrepancies from the study as planned have been explained.

Ethical: This study follows all ethical practices during writing.

\section{Contents}

1. Introduction

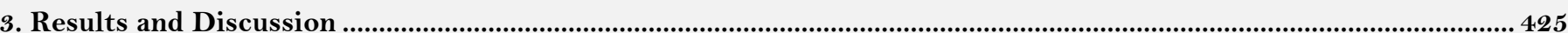

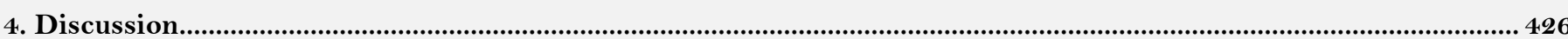

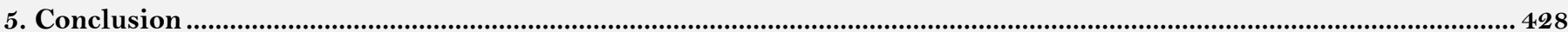

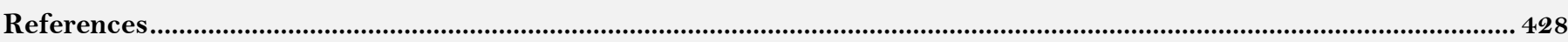




\section{Contribution of this paper to the literature}

The result of this research strengthen the theory of guided inquiry learning model which had an effect toward the creativity of children in kindergarten. The application of guided inquiry learning model also interacted with the social interaction ability owned by the children. The children who had a high social interaction would be more efficient if they were taught by using guided inquiry learning model in achieving the students' creativity, meanwhile the students who had a low social interaction would be more efficient if they were taught by using conventional learning model. So, the children's social interaction ability needs to be identified before applying the appropriate learning model.

\section{Introduction}

This study was an effort in preparing high quality human resources. In relation to this, earlier education is one of the efforts of starting education at the earliest time since birth time up to age 6. Early education is based on age group and type of service, which consists of; a) early education service for children from birth time up to age six which consists of a day care center, the same type early education unit and the equivalent, b) early education for ages two to four that consists of play group and the equivalent, c) early education for ages four to six that consists of kindergarten / raudhatul athfal/ bustanul athfal and the equivalent. Children of ages four to six who enter kindergarten are grouped into group A for ages four to five and group B for ages five to six.

Ages of five to six are the ages of preparation for entering elementary education. The education in these ages uses stimulations by using various skills and physical, motor, cognitive, language, social emotional condition, art, religious values and moral values. Children like to learn and explore the world with all its potentials. The beginning of childhood which include ages five to six is regarded the time for learning since at these ages children are brave so that they like to try new things to master various skills (Elizabeth, 2012).

Bravery and the pleasure in trying new things are the potential that enables children to learn many things. In developing their potentials, teachers need to help children develop various skills and knowledge though stimulations with physical activity, imagination, thinking ability and problem solving. Solving problems needs critical thinking ability in finding and determining various possible alternative solutions. Thinking ability, imagination, and creating something that is resulted from child's creativity through processing unique and useful ideas. Every child has creative potential in his or herself, which means that actually it is natural that every child is creative It implies that preschool child's creativity can be stimulated by giving the child to think divergently (Mary, 2002).

Traditional education is strongly oriented toward quantity and depends solely on knowledge and is considered unable to supply them students with competencies that are necessary in life. Hence, the type of education that is wanted now is education that takes part contextually (Marhaeni \& Artini, 2015). Teachers who are competent in planning, designing, and implementing appropriate teaching in developing creativity ability will be able to select and utilize an appropriate teaching model. The teaching has to be designed correctly in the form of learning experiences that meet the curriculum expectation (Marhaeni \& Artini, 2015). Guided inquiry is one of the models of teaching that is oriented toward children and provides opportunities for children to have learning experience and construct the children's knowledge. Teachers who have training experience and good understanding of principles and models of teaching based on inquiry are more able to plan and apply inquiry activities that are students' centered so that the students will have control of their own learning (Kong \& Song, 2014). Guided inquiry learning model gives freedom to learn to children by exploration, questions posting, discussing and presenting the results. Through this teaching model children's creativity potentials can be developed by stimulating the students' curiosity, imagination and problem solving.

The result of an interview with some teachers of early child education, heads of kindergartens and chair of Ikatan Guru Taman Kanak-Kanak ( IGTKI) / Kindergarten Teacher Association in North Kuta district indicated that in the teaching process teachers of early child education to feel more comfortable to implement the type of teaching that is commonly implemented in which the teacher is still the major source of information. This may have been caused by the teacher's limited knowledge about various teaching models, the limited ability to manage and implement teaching models, and the uncomfortable feeling of the teaching models. The result of a preliminary study showed that $61 \%$ of teachers never implemented guided inquiry learning (Cahaya, 2018).

In selecting teaching models for early education children a teacher has to pay attention and considers some things which include suitability with children's age, children's level of cognitive development, teacher's ability and readiness to prepare and manage teaching, suitability with the objectives and children's developmental achievements. Vygotsky introduced an interesting idea about the relation between learning and development (John, 2008). This idea specifically reflects his view that cognitive function comes from social situation. His concept was the zone of proximal development (ZPD), that is, a series of tasks that are difficult to be mastered by a child independently but can be learned with the help from an adult or a more able child. The technique that is related to ZPD is scaffolding, that is, a technique to change the level of support along the teaching process by a more able person (a teacher or a smarter friend) which adjusts the amount of guidance to the child's ability. After the child's ability increases, the guidance or support can be reduced. Researchers found that when scaffolding is used by the teacher and peers in collaborative learning, the child will be helped in his or her learning process (PressIey, John, \& Wolfgang, 1987). This principle is suitable for children of early ages.

The inquiry learning model is a teaching model that focuses on children, in which they are engaged in a problem or in search of an answer to questions in a procedure and group structure that is clearly designed. Trowbridge \& Bybee, 1990 grouped inquiries into three levels, namely simple inquiry (discovery), guided inquiry and open inquiry based on the role of the teacher and students in the inquiry process. In a simple inquiry the teacher formulates problems and work procedure and the students are facilitated to work and identify the results (Rizima, 2013). Guided inquiry can be applied in the process of teaching children of early ages.

Guided inquiry is a teaching model in which the teacher gives examples, specific topics and guide children to understand the topics. This model is effective for encouraging children to be involved and motivating them and 
helping them to a deeper and clearer understanding about the topics that they learn (Paul \& Don, 2012). The teaching with guided inquiry encourages and motivates children to learn topics through examples and the role of the teacher as facilitator.

Guided inquiry also applies an educational system which was developed by Indonesia's Father of Education, Ki Hajar Dewantara, namely the Among System which is a method that is based on case and dedication based on love. The education that follows the Among System is based on two things, namely the power of nature as the condition for bringing to life and reaching progress quickly and freedom as the condition for bringing to life and moving physical and mental strengths of children to enable them to live independently. The Among System is often associated with the principle of Ing ngarso sung tulodo, Ing madya mangun karsa, Tut Wuri Handayani (Washington, 2001). The level of the mastery of the object of children taught with constructivist approach that is based on inquiry is better than that of those taught with the conventional model (Putrayasa, 2013).

Inquiry learning process as explained above corresponds with the principle of scaffolding, the teacher as facilitator who guides children gradually and the amount of guidance is reduced in keeping with the level of development so that the children will be able to learn various things according to their ways, interests, needs and levels of understanding. By developing children's creativity through inquiry learning it is expected that we can meet the demands of the $21^{\text {st }}$ education in preparing students to master knowledge and skills to succeed as effective citizens, workers and leaders in line with the goals of the $21^{\text {st }}$ education or $4 \mathrm{C}$ 's supper skills: creativity, communication, critical thinking, and collaboration.

Some studies on guided inquiry show that the result of social studies learning of children who were taught with guided inquiry was higher than that of those who were taught with the conventional method (Eyiuche \& Oge, 2013). Inquiry based teaching also has a significant effect on the cognitive learning process (Zaini, 2016). It enhances critical thinking ability, problem formulation, hypothesis formulation, data collection and analysis, and conclusion drawing. The students' level of performance of the children who were treated with traditional method and process oriented guided inquiry learning showed that process oriented guided inquiry can enhance the level of performance and academic achievement better than the traditional teaching method (Villagonzalo, 2014). Children tend to learn better in a cooperative environment and the lesson is presented using process oriented guided inquiry learning model.

The opportunity to interact socially with others is a very important factor in children's development. Through the social interaction the children start to know and develop their own identity and to understand other people. The ability to interact strengthens children in exploring, investigating, posing questions, and stating many ideas without fear. Children who mostly interact with their environment have many opportunities to learn and undergo experiences in an increasingly wider environment. Some factors that can influence creativity include students and creative teaching (Gupta, 2015). Personal quality, cognitive style, family factor, education and carrier experience, belief, self-effort, motivation, the teacher's knowledge, fear to fail, collaboration and cooperation, competition and conflict, and creative experience can influence teacher's creativity and teachers teaching behavior. Children's creativity potential will become actualized optimally in a supporting environment, since all of children's ideas and imagination can be expressed openly when adults and peers appreciate and admit the children's creativity ability.

The ability to interact with peers is a supporting factor for the child in learning process. Social interaction ability will facilitate children to adapt and develop partnership with their friends as to enable them to develop linguistic ability in obtaining learning experiences optimally. Good social interaction ability plays an important role in linguistic development and social relation that support and motivate children in sharing, playing, and spending time together (Piker \& Rex, 2008). Through guided inquiry learning and with the support from social interaction ability will support children in enhancing their linguistic ability, since this teaching encourages and trains children to use language in every stage and activity.

Children's creativity is supported by their social interaction ability social interaction ability is the means to develop relations, communication and partnership with others and the environment. This ability enables children to communicate and socialize with the environment. This ability will give self-confidence to the children to express and communicate their various creative ideas to other people. Based on the theoretical explanation, relevant research findings and the result of the preliminary observation a study was conducted with the goal of analyzing the effect of guided inquiry learning on children's creativity viewed from social interaction ability among the kindergarten children of group B in North Kuta district, Badung regency.

\subsection{Research Focus}

This study analyzed the effect of guided inquiry learning model on creativity viewed from social interaction skill of the kindergarten children of group B in North Kuta district, Badung regency.

\section{Methods}

\subsection{Study Design}

This study used factorial design. The researcher determined the effect of two independent variables both separately and the effect of interaction between the independent variables. The effect of each independent variable is called the main effect. The effect of interaction between two or more independent variables is called the interaction effect (Gall, Joyce, \& Walter, 2003). The factorial design is an elaboration of true experiment and enables the research to study two or more variables separately or the interaction between variables (Gay, 1987). The factorial design used in this study was the $2 \times 2$ design. The study constellation is presented in the following Table 1. 
Table-1. Study Design.

\begin{tabular}{c|c|c}
\hline \multicolumn{2}{c|}{ Teaching Model } \\
$\begin{array}{c}\text { Social Interaction } \\
\text { Ability }\end{array}$ & Guided Inquiry Learning $\left(\mathrm{A}_{1}\right)$ & $\begin{array}{c}\text { Model Conventional Teaching } \\
\left(\mathrm{A}_{2}\right)\end{array}$ \\
\hline $\begin{array}{c}\text { High } \\
\left(\mathrm{B}_{1}\right)\end{array}$ & $\left(\mathrm{A}_{1} \mathrm{~B}_{1} \mathrm{Y}\right)$ & $\left(\mathrm{A}_{2} \mathrm{~B}_{1} \mathrm{Y}\right)$ \\
\hline $\begin{array}{c}\text { Low } \\
\left(\mathrm{B}_{2}\right)\end{array}$ & $\left(\mathrm{A}_{1} \mathrm{~B}_{2} \mathrm{Y}\right)$ & $\left(\mathrm{A}_{2} \mathrm{~B}_{2} \mathrm{Y}\right)$ \\
\hline
\end{tabular}

$\mathrm{A}_{1}$ : the group of children treated with guided inquiry teaching model.

$\mathrm{A}_{2}$ : group of children treated with conventional teaching.

$\mathrm{B}_{1}$ : the group of children with a high social interaction ability.

$\mathrm{B}_{2}$ : group of children with a low social interaction ability.

Y: children's creativity.

The teaching model tested in this study was guided inquiry learning. The experiment group learned through guided inquiry learning model. Before this study was conducted at school the teaching was done using the conventional teaching. Thus, the control group was treated with the conventional teaching model. The same material was given to the two groups or the experiment and the control groups. The sequence of material presentation in the two groups was the same. The difference lay in the models of teaching used.

In this study guided inquiry learning model is defined as the teaching model that enables children to play the role of active learning agents in constructing knowledge and experience through directions and clues in the form of questions by doing investigation, exploration, investigation, search, examination, and research that use instruments and learning resources through scaffolding process. The teaching syntax for the experiment group followed guided inquiry learning model which can be summed up on Table 2.

Table-2. Syntax of the experiment group teaching.

\begin{tabular}{|c|c|}
\hline Stages & Children's activities \\
\hline$\overline{\text { Posing questions }}$ & $\begin{array}{ll}\text { a. } & \text { Forming groups } \\
\text { b. Answering questions asked by the teacher } \\
\text { c. Listening to objectives and teaching materials } \\
\text { d. Listening to the coverage of the teaching materials }\end{array}$ \\
\hline Finding answers & $\begin{array}{l}\text { a. Observing pictures shown by the teacher (observing) } \\
\text { b. Answering question asked by the teacher } \\
\text { c. Making hypothesis (collecting information) }\end{array}$ \\
\hline $\begin{array}{l}\text { Exploring } \\
\text { probabilities }\end{array}$ & $\begin{array}{l}\text { a. } \\
\text { b. Preparing tools and materials } \\
\text { c. } \\
\text { d. Doing a group discussion } \\
\text { d. Doing group work in student's worksheet based on the result of observation and discussion }\end{array}$ \\
\hline Presenting findings & $\begin{array}{l}\text { a. Presenting the result of group work in front of the class } \\
\text { b. Giving a response to the result of the presentation of the group who presented the result } \\
\text { c. Listening to the reinforcement of concept that have been presented by the teacher } \\
\text { d. Listening to examples of the application examples in daily life } \\
\text { e. Concluding teaching materials with the teacher's guidance } \\
\text { f. Doing individual task in student's worksheet }\end{array}$ \\
\hline
\end{tabular}

\subsection{Population and Sample}

The population of this study was all kindergarten B's in North Kuta district with the total number of 1,951 children, consisting of 49 schools, divided into seven clusters. The sample was drawn by using a multistage random sampling technique.

According to Creswell the steps of sampling in multistage random sampling is as follows:

(1) determining the site of study as population, selecting $25 \%$ randomly based on clusters, so that the reachable population in this study was two clusters, namely Gugus Mawar and Gugus Cempaka that consisted of 29 kindergartens with the total number of 718 children.

(2) finding learning groups randomly, thus eight learning groups were selected with the total number of 152 children.

(3) determining four experimental groups with 76 children and four control groups with 76 children selected randomly as shown in Table 3.

Table-3. Sample of the study.

\begin{tabular}{|c|c|c|c|c|}
\hline \multirow[b]{2}{*}{ No. } & \multirow[b]{2}{*}{ Cluster } & \multicolumn{3}{|c|}{ Sample } \\
\hline & & Kindergarten Name & $\begin{array}{c}\text { Eksperiment } \\
\text { group }\end{array}$ & $\begin{array}{l}\text { Control } \\
\text { group }\end{array}$ \\
\hline \multirow{4}{*}{1.} & \multirow{4}{*}{ Mawar } & Widya Kumara Umalas & - & 19 \\
\hline & & Thomas Aquino & 24 & - \\
\hline & & Dharma Kumara I Tibubeneng & - & 26 \\
\hline & & Widya Puspita & 19 & - \\
\hline \multirow{4}{*}{2.} & \multirow{4}{*}{ Cempaka } & Dewi Kunti I & 18 & - \\
\hline & & Tunas Mekar I & - & 15 \\
\hline & & Dewi Kunti II & - & 16 \\
\hline & & Tunas Mekar II & 15 & - \\
\hline \multicolumn{3}{|c|}{ Total } & 76 & 76 \\
\hline
\end{tabular}

Source: UPT Kec. Badung (2019). 


\subsection{Instruments for Collecting Data}

The data collected in this study were on social interaction ability and creativity. To collect the data needed in this study, some instruments were used: an observation sheet of social interaction and an observation sheet of creativity. The observation sheet of social interaction was used to collect data on social interaction (reliability = 0.99). The observation sheet consisted of 10 indicators. The observation sheet of creativity was used to collect data on creativity (reliability $=0.99$ ). The observation sheet consisted of 8 indicators. The indicators of social interaction as shown in Table 4 and the indicators of creativity as shown in Table 5.

\begin{tabular}{|c|c|}
\hline Social Interaction Dimension & Indicator \\
\hline Self-Awareness & $\begin{array}{l}\text { 1. Shows one's ability to adapt to the situation } \\
\text { 2. Knows one's feeling and manage it naturally (controlling oneself } \\
\text { naturally) }\end{array}$ \\
\hline $\begin{array}{l}\text { Sense of responsibility for oneself } \\
\text { and others }\end{array}$ & $\begin{array}{l}\text { 1. } \\
\text { 2. }\end{array}$ \\
\hline Prosocial behavior & $\begin{array}{l}\text { 1. Plays with peers } \\
\text { 2. Shares with others } \\
\text { 3. Respects others' rights/ opinions/ works } \\
\text { 4. Shows tolerance attitude } \\
\text { 5. Knows etiquette and politeness according to the local sociocultural } \\
\text { values }\end{array}$ \\
\hline
\end{tabular}

Table-5. Dimensions and Indicators of Creativity

\begin{tabular}{|c|c|}
\hline Dimensions of Creativities & Indicators \\
\hline Fluency & Gives many ideas \\
\hline Flexibility & $\begin{array}{l}\text { 1. Often selects answers different from peers' } \\
\text { 2. Does not find difficulty when facing problems }\end{array}$ \\
\hline Originality & $\begin{array}{l}\text { 1. Has different ways in using tools and materials for playing } \\
\text { 2. Introduces and makes new creations from old }\end{array}$ \\
\hline Problem sensibility & Likes to give ideas/solutions to a problem \\
\hline Elaboration & $\begin{array}{l}\text { 1. Likes challenging things } \\
\text { 2. Likes making something from things available in the } \\
\text { environment }\end{array}$ \\
\hline
\end{tabular}

Source: Alia (2013)

\subsection{Data Analysis Technique}

There were three stages of data analysis in this study, namely (1) data description, (2) testing analysis prerequisites and (3) hypothesis testing. The data analysis in this study covered descriptive analysis, prerequisite testing, and inferential analysis. The descriptive analysis yielded mean (M) and standard deviation (SD). Then, prerequisite testing consisted of two-way ANOVA to test the hypothesis of the study that was continued to post hoc test. To test it SPSS 17.0 was used.

\section{Results and Discussion}

The result of analysis of data on children's creativity based on the teaching model and social interaction ability can be seen on Table 6. Based on Table 6 two hypotheses were tested, namely: 1) there is a difference in creativity between children who learned with guided inquiry learning model and those who learned with the conventional teaching among the kindergarten children of group B in North Kuta district, Badung regency, and 2) there is the effect of interaction between teaching model and social interaction ability on creativity among the kindergarten children of group B in North Kuta district, Badung regency.

Table-6. Mean of Children's Creativity (Y)

\begin{tabular}{c|c|c|c}
\hline Teaching Model & $\begin{array}{c}\text { Guided Inquiry } \\
\text { Teaching Model (A 1) }\end{array}$ & $\begin{array}{c}\text { Conventional Teaching } \\
\text { Mocial Interaction } \\
\text { Ability (B) }\end{array}$ & Total \\
\hline High (B 1$)$ & $\mathrm{Y}=34.04$ & $\mathrm{Y}=30.20$ & $\mathrm{Y}=32.12$ \\
\hline Low $(\mathrm{B} 2)$ & $\mathrm{Y}=29.08$ & $\mathrm{Y}=28.92$ & $\mathrm{Y}=29.00$ \\
\hline Total & $\mathrm{Y}=31.56$ & $\mathrm{Y}=29.56$ & \\
\hline
\end{tabular}

Before testing hypotheses prerequisite testing was done first that covered normality testing, and homogeneity testing. Normality testing was done with Kolmogorov - Smirnov test. The result of analysis for all data groups of children's creativities yielded a significance level less than 0.05. Thus it can be concluded that all groups of data on children's creativity in this study came from a population with a normal distribution. Variance homogeneity testing was done using F-test and Bartlet Test. The result of the test showed that $\mathrm{F}_{\text {obs. }}$ was smaller than $\mathrm{F}_{\text {c.v. }}$ so that the data on children's creativity for the groups who learned with teaching models and social interaction ability have homogeneous variances. Since the prerequisite testing has been met, the testing of hypotheses can be done and the results can be seen in Table 7 . 
Table-7. Result of Hypothesis Testing

\begin{tabular}{c|c|c|c|c|c|c}
\hline \multirow{2}{*}{ Source } & Dependent Variable & $\begin{array}{c}\text { Sum of } \\
\text { squares }\end{array}$ & df & $\begin{array}{c}\text { Mean } \\
\text { square }\end{array}$ & F & Sig. \\
\hline Corrected Model & $\mathrm{Y}$ & 428.000 & 3 & 142.667 & 26.927 & 0.000 \\
\hline Intercept & $\mathrm{Y}$ & 93391.360 & 1 & 93391.360 & 17627.663 & 0.000 \\
\hline $\mathrm{A}$ & $\mathrm{Y}$ & 100.000 & 1 & 100.000 & 18.874 & 0.000 \\
\hline $\mathrm{B}$ & $\mathrm{Y}$ & 243.360 & 1 & 243.360 & 45.931 & 0.000 \\
\hline $\mathrm{A} * \mathrm{~B}$ & $\mathrm{Y}$ & 84.640 & 1 & 84.640 & 15.975 & 0.000 \\
\hline Error & $\mathrm{Y}$ & 508.640 & 96 & 5.298 & & \\
\hline Total & $\mathrm{Y}$ & 94328.000 & 100 & & & \\
\hline Corrected Total & $\mathrm{Y}$ & 936.640 & 99 & & & \\
\hline
\end{tabular}

Based on Table 7 the results of the hypothesis testing are : 1) there is a difference in creativity between children who learned with guided inquiry learning model and those who learned with the conventional teaching model among the kindergarten children of group B in North Kuta district, Badung regency $(\mathrm{F}=18.874$ BS $\mathrm{P}<0.05)$, and 2) there is the effect of interaction between teaching model and social interaction ability on creativity among the kindergarten children of group B in North Kuta district, Badung regency. $(\mathrm{F}=15.975$ and $\mathrm{p}<0.05)$. The interaction between teaching model and social interaction ability on children's creativity is shown by Table 2 .

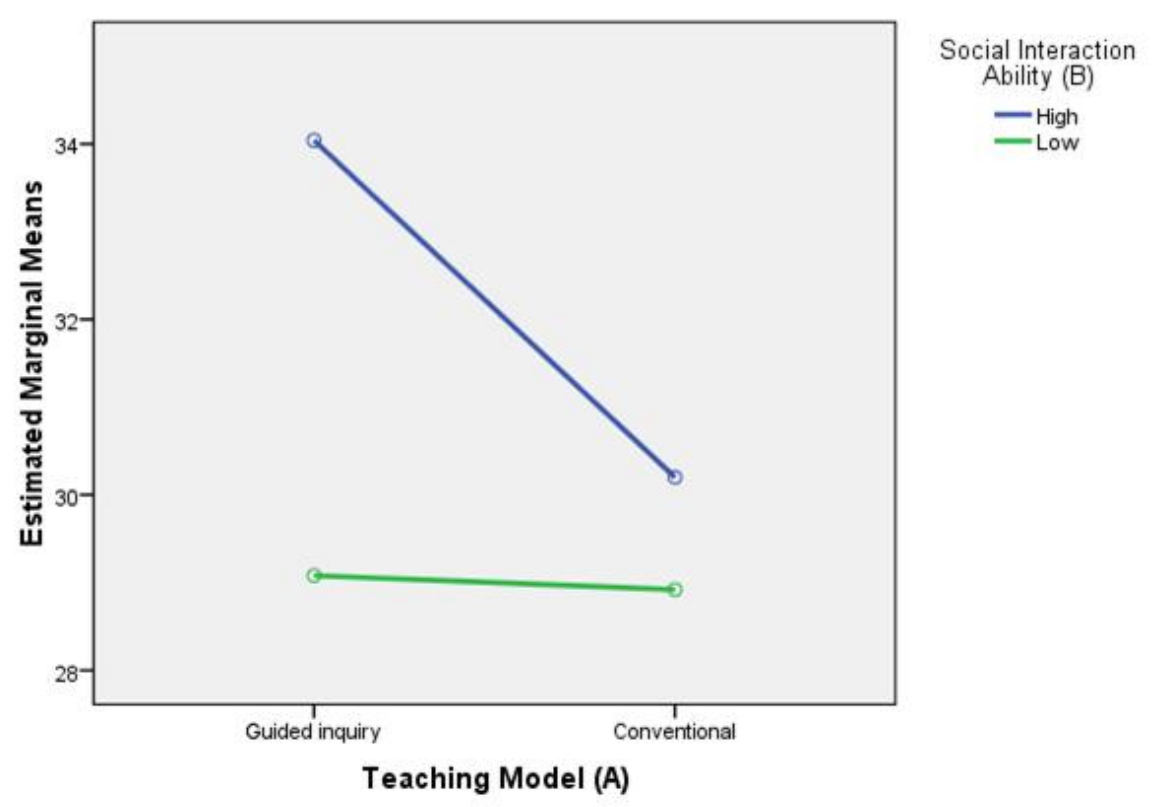

Figure-1. Interaction between teaching model and social interaction ability on creativity.

Figure 1 shows that 1 ) for children with a high social interaction ability, the mean of creativity of the children who learned with guided inquiry learning model (34.04) was higher than that of the children who learned with the conventional teaching model (30.20) and 2) for children with a low social interaction ability, the mean of creativity of the children who learned with guided inquiry learning model (29.08) was slightly higher than that of the mean of creativity of those who learned with the conventional teaching model (28.92).

\section{Discussion}

\subsection{The Effect of Guided Inquiry Learning Model on Children's Creativity}

Based on the results of data analysis it has been proven that there was a significant difference in creativity between children who learned with guided inquiry learning model and those who learned with the conventional teaching model among kindergarten children of group B in North Kuta district, Badung regency. The mean of creativity scores in the group of children who learned with guided inquiry learning model was 31.56, which was higher than that of the group who learned with the conventional teaching model (29.56).

Eggen \& Khaucak state that guided inquiry learning model encourages and motivates children to be involved in a learning process (Marhaeni, 2012). The more involved the children are in the learning process, the higher their learning ability, and this has an effect on their creativity. Marhaeni states that innovative teaching has a childcentered perspective. This teaching model can optimize all the potential of the children, including their creativity (Marhaeni, 2012). If the teaching model implemented is more centered on the teacher the children's involvement will be less. The teaching that involves children less will make the teaching less meaningful for the children.

Learning through innovation also supports very much the process of children-centered teaching. Coffman (2009) states that guided inquiry learning is the implementation of constructivist approach in which children interact by asking questions in improving the understanding. The teacher does not teach everything directly or explicitly. On the other hand, the student is encouraged to find knowledge, to produce regulations and to apply them for facing daily life situations. In inquiry teaching, the teacher becomes a facilitator who helps students in exploring and finding concepts so that the teaching becomes more challenging.

The involvement of children in the child centered teaching can be shown in creativity, for example, in the processes of observation, data analysis, discussion and communication of the observation result. Chen states that guided inquiry learning model is a teaching model that is important in the teaching process since it involves various classroom activities such as asking questions, doing observations, reading books and other resources of information, analyzing data and communicating the results which make it possible for the students to participate 
fully to enhance their curiosity both in the classroom and outside, and make them develop personal enthusiasm, initiative, cooperation, unity and decision making among themselves which of course can improve their creativity.

The result of this study was supported by a study by Lew and Jungwon (2013) that shows that there is a significant relation between motivation and children's creativity if the learning takes place in a creative environment. The result was also confirmed by $\mathrm{Lu}$ who states that children can express free creativity after being given opportunities and motivation (Chou, 2014). The creative environment can be obtained from guided inquiry learning model. The result of the study conducted by (Rachmawati, Yeni, \& Euis, 2010) shows that guided inquiry based teaching can train students' creative skills.

Based on the explanation above it can be concluded that there was a difference in creativity between children who learned with guided inquiry learning model and those who learned with the conventional teaching model among kindergarten children of group B in North Kuta district, Badung regency. The children's mean in creativity of those who learned with guided inquiry learning model was higher than that of those who learned with the conventional teaching model.

\subsection{The Effect of Interaction between Teaching Model and Social Interaction Ability on Children's Creativity}

Based on the result of statistical tests it was found that there was a significant effect of interaction between teaching model and social interaction ability on creativity among kindergarten children of group B in North Kuta district, Badung regency. For the children with a high social interaction ability the mean in creativity of the children was higher than that of those who learned with the conventional teaching model. For children with a low social interaction ability, the mean in creativity of those who learned with guided inquiry learning model was slightly higher than that of those who learned with the conventional teaching model.

Soerjono (2013) states that social interaction is the basis for social process that occurs because of the presence of a dynamic social relation. The social interaction is a contact or reciprocal relation or inter stimulation and responses among individuals, among groups or between individuals and group. This means that with social interaction ability, an individual relation with others or the community can occur in a harmony since with the presence of interactions between an individual and another individual they will understand each other. Thus, the difference in contact or reciprocal relation during the learning process obviously causes the difference in the children's creativity. Similarly, the difference in the way the children in contact or reciprocal relation in solving problems through guided inquiry learning and those in the conventional teaching also caused a difference in children's creativity.

Social interaction abilities that were involved in this study were high social interaction ability and low social interaction ability. High and social interaction abilities are behaviors that are shown by children in relating to the environment. Children with a high social interaction ability are those who can adapt to the environment, to be careful, responsible for themselves and others and who show tolerance attitude. Children with a low social interaction ability are those who are less able to adapt themselves to the environment, less careful, less obedient to regulations and like to be alone.

Based on the explanation of the characteristics of children with a high social interaction ability, then guided inquiry teaching is more suitable for the children with a high social interaction ability. Guided inquiry learning makes it possible to speed up the development of children's creativity in observation, making hypotheses, collecting data, testing hypotheses, and communicating results. Of course, these activities will be easy to perform by children with a high social interaction ability. Thus, guided inquiry teaching is very suitable for children with a high social interaction ability. This is proved by looking at the gain in mean in creativity of both groups as shown in Figure 2.

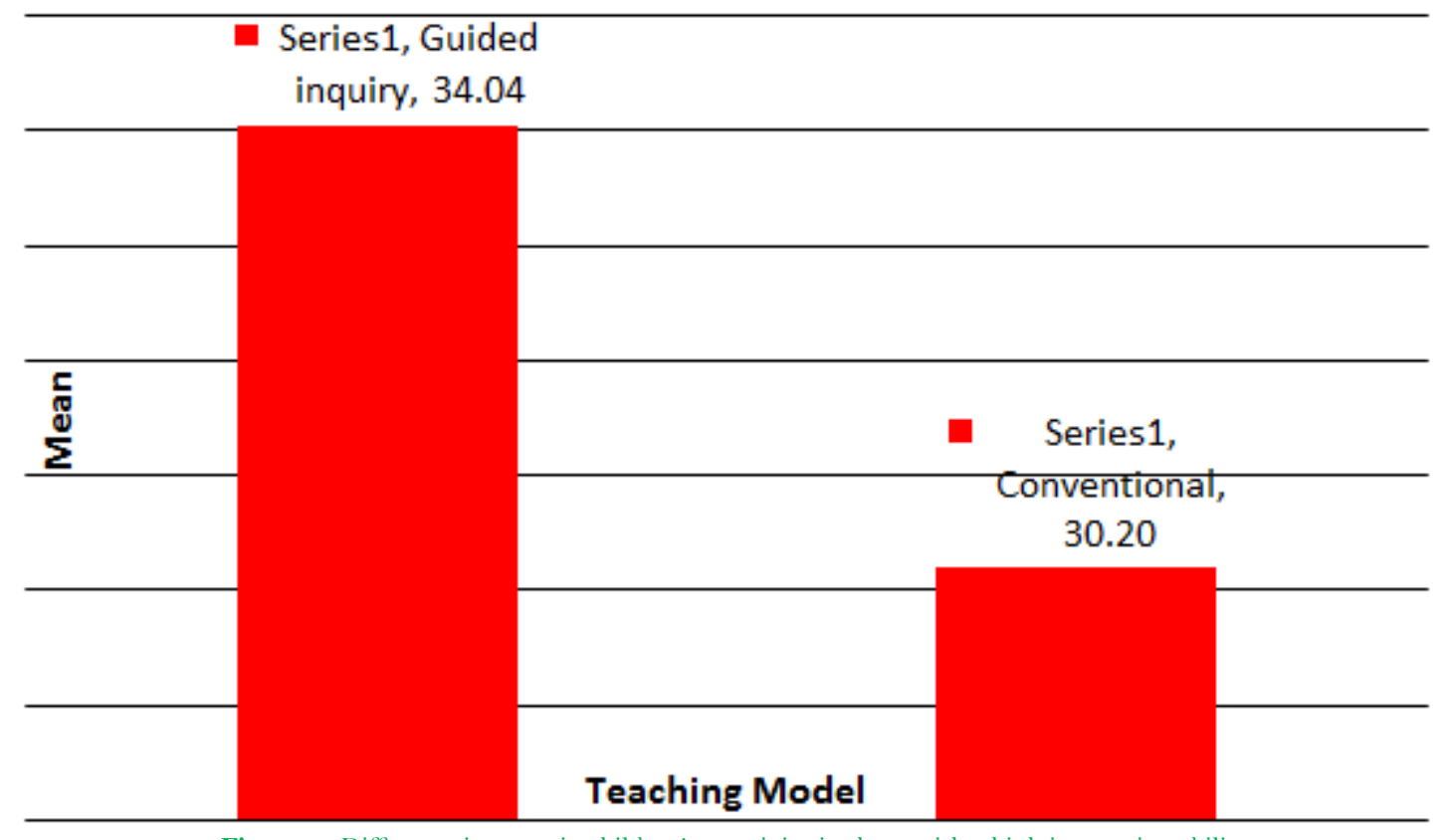

Figure-2. Difference in mean in children's creativity in those with a high interaction ability.

On the other hand, children with a low social interaction ability are those who are less able to adapt to the environment, less careful, less obedient to regulations, and like to be alone. The characteristics of the children with a low interaction ability is more suitable for the conventional teaching model. The conventional teaching model is characterized more by transfer of knowledge from the teacher in which the teacher is far more active than the children.

Based on the explanation it is clear that the interaction between teaching model and social interaction ability have an effect on children's creativity. Children with a high social interaction ability are more suitable for the 
guided inquiry teaching while those with a low interaction ability are more suitable for the conventional teaching. The result of this study supports that statement that for children with a high interaction ability the mean in creativity for those who learned with guided inquiry learning model was higher than that of those who learned with the conventional teaching method. For children with a low social interaction ability, the mean in creativity of those who learned with guided inquiry learning model was lower than that of those who learned with the conventional teaching model. This difference can also be seen from the mean in creativity of the children with a low interaction ability as shown in Figure 3.

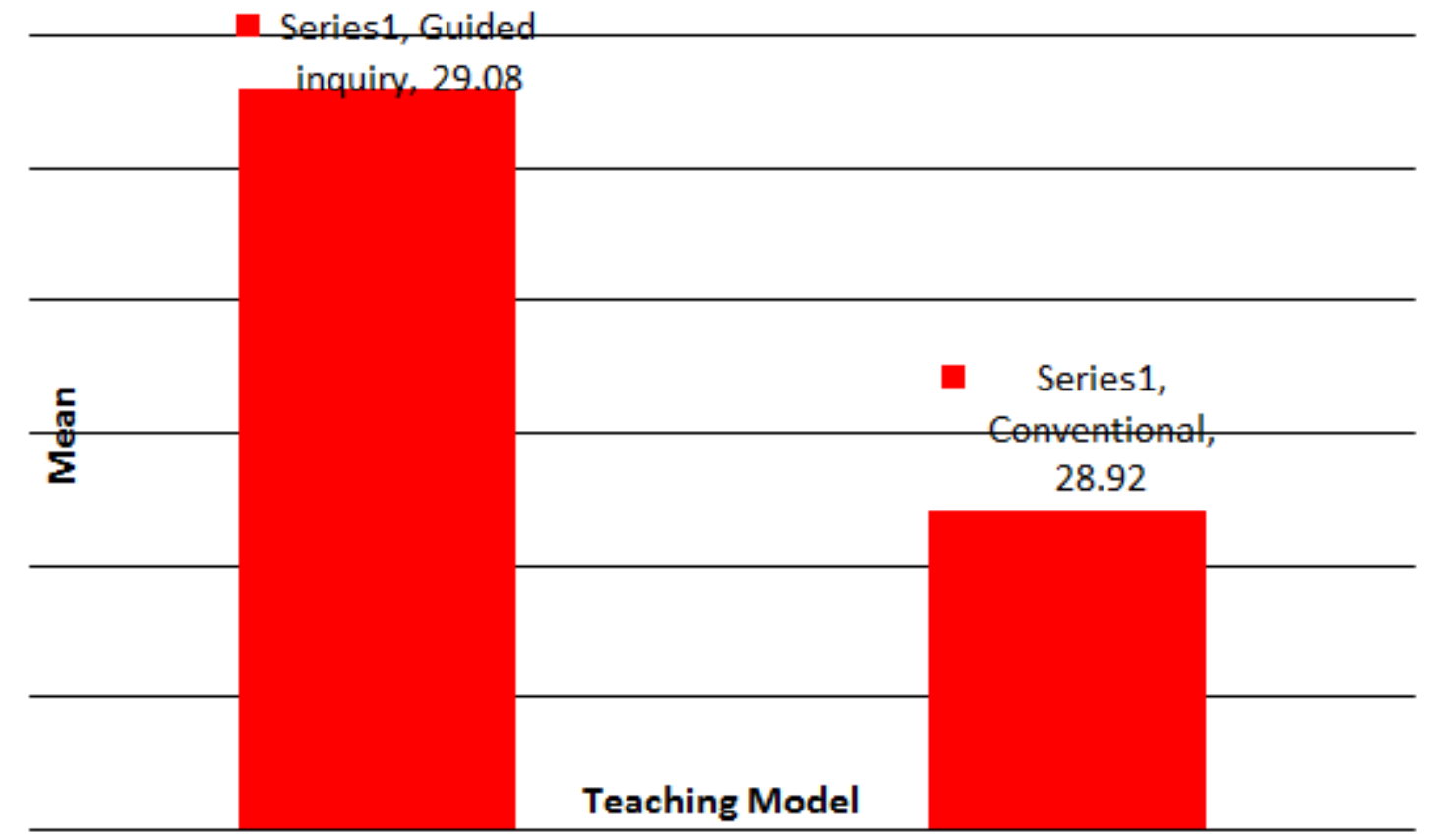

Figure-3. Difference in Mean in Creativity of Children with a Low Social Interaction Ability.

The result of this study is supported by the statement given by Chaplin (2006) that social interaction is a reciprocal process among individuals with groups that covers openness, cooperation, frequency in relation. According to Wila (1982) social interaction is a relation between two or more human beings who influence each other, change the behavior of other individuals or on the other way around. This implies that if social interaction ability is low this causes less openness, less cooperation, and low frequency of relation that make children have a low creativity.

\section{Conclusion}

Based on the result of data analysis and the discussion of the result it can be concluded that: (1) there was a significant difference in creativity between children who learned with guided inquiry learning and those who learned with the conventional teaching among kindergarten children of group B in North Kuta district, Badung regency. The mean in creativity in the group of children who learned with guided inquiry learning model was 31.56 or higher than that of the group of children who learned with the conventional teaching (29.56). (2) there was a significant effect of interaction between teaching model and social interaction ability on creativity among kindergarten children of group B in North Kuta district, Badung regency. In the children with a high social interaction ability the mean in creativity of those who learned with guided inquiry model (34.20) was higher than that of those who learned with the conventional teaching model (30.20). The same is true for the children with low social interaction ability; the mean in creativity of those who learned with guided inquiry teaching model (29.08) is slightly higher than that of those who learned with the conventional teaching (28.92).

\section{References}

Alia, A. O. (2013). Creative characteristics and its relation to achievement and school type among Jordanian students. Creative Education, 4(1), 29-34.

Cahaya, I. M. (2018). Preliminary study the effect of guided inquiry learning model on creativity and language ability in terms of the social interaction ability of group B Kindergarten children in North Kuta District, Badung Regency. Research Report. Badung: Dhyana Pura University.

Cahaya, I. M. (2020). The influence of guided inquiry learning model on creativity and language ability in terms of the social interaction ability of group B Kindergarten children in North Kuta District, Badung Regency. Dissertation. Singaraja: Ganesha University of Education.

Chaplin, J. P. (2006). Complete psychology dictionary. Jakarta: PT. Raja Grafindo Persada.

Chou, M. J. (2014). In celebration of creativity play: An exploration on children's aesthetic sensibility and creativity in waldorf early childhood education. Social Intervention Research Journal, 47, 165-179.

Coffman, T. (2009). Engaging students through inquiry-oriented learning and technology. Maryland: Rowman \& Littlefield Education.

Elizabeth, H. B. (2012). Developmental psychology: A lifespan approach translation of Istiwidayanti \& Soedjarwo (5th ed.). Jakarta: Erlangga.

Eyiuche, O., \& Oge, E. K. (2013). Effects of guided inquiry method on secondary school students' performance in social studies curriculum in Anambra State, Nigeria. British Journal of Education, Society \& Behavioural Science, 3(3), 206-222.

Gall, M. D., Joyce, P. G., \& Walter, R. B. (2003). Education research: An introduction (7th ed.). Boston: Allyn and Bacon.

Gay, L. R. (1987). Educational research; competencies for analysis and application (3rd ed.). Ohio: Merrill Publishing Company.

Gupta, S. (2015). Development of creativity: Interplay of biological, psychological and social factors. International Journal of ResearchGranthaalayah, 3(12), 195-202.

John, S. W. (2008). Educational psychology (2nd ed.). Jakarta: Kencana: Tri Wibowo B.S.

Kerlinger, F. N. (2000). Asas-asas penelitian behavioral. Terjemahan: Foundation behavioral research, oleh: Simatupang, L. R., E Koesoemanto, H. J. Yogyakarta: Gadjah Mada University Press.

Kong, S. C., \& Song, Y. (2014). The impact of a principle-based pedagogical design on inquiry-based learning in a seamless learning environment in Hong Kong. International Forum of Educational Technology \& Society, $17(2), 127-141$.

Lew, K.-H., \& Jungwon, C. (2013). Creativity analysis for smart specialist of the ubiquitous Era. International Journal of Smart Home, 7(4).

Marhaeni, A. A. I. N. (2012). Foundations and learning innovations. Singaraja: Ganesha University of Education. 
Marhaeni, A. A. I. N., \& Artini, L. P. (2015). Authentic assessment and meaningful education: Implementation of the 2013 curriculum. Indonesian Education Journal, 4(1), 499-511.

Mary, M. (2002). Creative activity for young children (7th ed.). Columbia: Delmar.

Paul, E., \& Don, K. (2012). Learning strategies and models: Teaching content and thinking skills (6th ed.). Jakarta: Index.

Piker, R. A., \& Rex, L. A. (2008). Influences of teacher-child social interactions on English language development in a head start classroom. Early Childhood Education Journal, 36, 187-193.

PressIey, M., John, G. B., \& Wolfgang, S. (1987). Cognitive strategies: Good strategy users coordinate metacognition and knowledge. Annals of Child Development, 4, 89-129.

Putrayasa, I. B. (2013). Tracing misconceptions in learning grammar with inquiry-based constructivism approach to class I students of Undiksha Singaraja Laboratory Middle School. Indonesian Education Journal, 2(2).

Rachmawati, Yeni, \& Euis, K. (2010). Creativity development strategy for Kindergarten children. Jakarta: Kencana Prenada Media Group.

Regulation of the Minister of Education and Culture of the Republic of Indonesia. (2014). No. 137 of 2014 concerning national standards for early childhood education. Jakarta: Ministry of National Education of the Republic of Indonesia.

Rizima, S. S. (2013). Science-based creative teaching and learning design. Jogjakarta: Diva Press.

Soerjono, S. (2013). Sociology an introduction (Revised ed.). Jakarta: Raja Grafindo.

Trowbridge, L. W., \& Bybee, R. W. (1990). Becoming a secondary school science teacher. Melbourne: Merill Publishing Company.

UPT Kec. Badung. (2019). Number of Students in Each Kindergarten. Badung: UPT Badung District.

Villagonzalo, E. C. (2014). Guided inquiry learning: An effective approach in enhancing students' academic performance. Paper presented at the DLSU Research Congress 2014 De La Salle University, Manila, Philippines March 6-8, 2014.

Washington, N. (2001). The University I love for. Jakarta: Indonesian National Commission for UNESCO.

Wila, D. A. (1982). Introduction to sociology. Surabaya: National Business.

Zaini, M. (2016). Guided inquiry based learning on the concept of ecosystem toward learning outcomes and critical thinking skills of high school students. IOSR Journal of Research ङ Method in Education (IOSR-JRME), 6(6), 50-55. 